\title{
Cystowithius ankeri sp. nov. (Arachnida: Pseudoscorpiones: Withiidae), a new pseudoscorpion from the Central Andes of Colombia
}

\author{
Fabián García' [D, Catalina Romero-Ortiz² (1)

\begin{abstract}
'Laboratório de Aracnologia, Coordenação de Zoologia, Museu Paraense Emílio Goeldi, Avenida Perimetral, 1901, Terra Firme, 66077-830, Belém, PA, Brazil.

${ }^{2}$ Laboratorio de Sistemática y Biología Comparada de Insectos, Instituto de Ciencias Naturales, Universidad

Nacional de Colombia, 111132 , Bogotá D.C., Colombia.

Corresponding author: Fabián Garcia (fdracochela@gmail.com)
\end{abstract}

http://zoobank.org/28E78A33-60FA-4B48-A59B-77B0D4404229

\begin{abstract}
A new species of the pseudoscorpion genus Cystowithius Harvey, 2004 is described based on several males and females collected in the Cordillera Central near Manizales and Villamaría, Caldas, Colombia. The type series was collected under or on the bark of Eucalyptus grandis W. Hill ex Maiden (Myrtaceae). Cystowithius ankeri sp. nov. is the fifth species in the genus, differing from its four congeners by several characters, including the position of the male sternal invaginations, the length of the movable finger of the pedipalp, and the tactile setae of tarsus IV situated subdistally. A revised identification key to the five species of Cystowithius is also presented. The first barcode (COI gene) of a species of this genus is also provided.

KEY WORDS. Arachnids, Cacodemoniini, Cheliferoidea, Eucalyptus, Withiinae.
\end{abstract}

\section{INTRODUCTION}

The cheliferoid family Withiidae Chamberlin, 1931 comprises 37 genera in two subfamilies: Paragoniochernetinae, restricted to southern Africa, and Withiinae, distributed worldwide (Harvey 2015). Cacodemoniini is the only group of the Withiinae that can be characterized using morphological characters, more precisely, by the separated lateral rods and a long ejaculatory canal formed not by the dorsal apodemes exclusively, but by a fusion of the dorsal and lateral apodemes (Romero-Ortiz and Sarmiento 2021).

Cystowithius Harvey, 2004 (Cacodemoniini) is known from the highlands of Central and South America, and can be differentiated from all other pseudoscorpion genera by the presence of paired, sac-like invaginations on the anterior margins of the sternites (Harvey 2004). The genus currently comprises four species: C. smithersi Harvey, 2004, the type species from Ecuador; C. chamberlini Harvey, 2004 from Guatemala and Mexico; C. ecuadoricus (Beier, 1959) from Ecuador and Peru; and C. colombicus Harvey, 2004 from Colombia.

A fifth species of the genus is described herein, based on male and female specimens found under or on the bark of eucalyptus trees in the municipalities of Manizales and Villamaría, Caldas, Colombia.

\section{MATERIAL AND METHODS}

The specimens were collected in 2018, 2019 and 2021, in the Jardín Botánico, Universidad de Caldas $\left(5.055^{\circ} \mathrm{N} ; 75.494^{\circ} \mathrm{W}\right)$ in Manizales, and Vereda Gallinazo $\left(5.015^{\circ} \mathrm{N} ; 75.439^{\circ} \mathrm{W}\right)$ in Villamaría, both located in the Colombian department of Caldas. All specimens were found by visual search, captured with the aid of a fine brush, and preserved in 96\% ethanol; some of them were photographed in situ. The specimens were first immersed in $75 \%$ lactic acid at room temperature for several days, then mounted on microscope slides and examined under an Olympus $\mathrm{CH}-2$ microscope. After examination, they were rinsed with distilled water and returned to $96 \%$ ethanol. The dissected appendages, such as legs I and IV, pedipalp and chelicera, were kept in microvials containing 96\% ethanol. Micro-photographs were taken with a MC $170 \mathrm{HD}$ camera mounted on a Leica M205A and later vectorized (Coleman 2009) on Adobe Illustrator C.C. 2020.

All measurements were made with a graticulate objective mounted on the microscope/stereomicroscope and are expressed in millimeters. Terminology and measurements mostly follow Chamberlin (1931a), with some minor modifications, e.g., for trichobothria (Harvey 2004), cheliceral rallum (Judson 2007) and genitalia (Romero-Ortiz and Sarmiento 2021). 
Type and non-type material of the new species is deposited in the following institutions: (ICN) Instituto de Ciencias Naturales, Universidad Nacional de Colombia, Bogotá D.C., Colombia; (NHMW) Naturhistorisches Museum, Vienna, Austria; (MPEG) Museu Paraense Emílio Goeldi, Belém, Brazil; (MNRJ) Museu Nacional, Rio de Janeiro, Brazil; (MUSENUV) Museo de Entomología de la Universidad del Valle, Cali, Colombia. Additionally, we examined photographs of specimens of other species of Cystowithius deposited in (CAS) California Academy of Science, San Francisco, USA; (MNHN) Muséum National d'Histoire Naturelle, Paris, France; and NHMW.

Other abbreviations used in the text: (b) basal trichobothrium, (bs) basal seta, (eb) exterior basal trichobothrium, (es) exterior seta, (esb) exterior subbasal trichobothrium, (est) exterior subterminal trichobothrium, (et) exterior terminal trichobothrium, (gls) glandular setae, (gs) galeal seta, (ib) interior basal, (is) interior seta, (isb) interior subbasal trichobothrium, (is) interior subterminal trichobothrium, (it) interior terminal trichobothrium, (sb) subbasal trichobothrium, (sbs) subbasal seta, (sos) suboral seta, (st) subterminal trichobothrium, (t) terminal trichobothrium, (ts) tactile seta.

For the COI barcode, we used primers LCO1490 and HCO2198 (Folmer et al. 1994) and followed the extraction and amplification protocol in Murienne et al. (2008).

\section{TAXONOMY}

\section{Withiidae Chamberlin, 1931b \\ Withiinae Chamberlin, 1931b \\ Cystowithius Harvey, 2004}

Cystowithius Harvey, 2004: 440 (type species Cystowithius smithersi Harvey, 2004, by original designation).

\section{Cystowithius ankeri García \& Romero-Ortiz sp. nov.} Figs $1-12,15$

\section{http://zoobank.org/28E78A33-60FA-4B48-A59B-77B0D4404229}

Type-material. Holotype male, COLOMBIA: Caldas, Manizales, Jardín Botánico de la Universidad de Caldas, $5.044^{\circ} \mathrm{N}$ $75.4894^{\circ} \mathrm{W}, 2150 \mathrm{~m}$, February $2021 \mathrm{~F}$. García leg., under bark of Eucalyptus grandis, ICN-APs-837.

Paratypes. 1 male, same collection locality as for holotype, August 2018, A. Anker and F. García leg., ICN-APs-682 [Genbank accession number (MT085822)]; 3 females, 5 males, same collection locality and collector as for holotype; August 2019, ICN-APs-766 (1 male), ICN-APs-767 (1 female), MUSENUV-Ar-2097 (1 male), MUSENUV-Ar-2098 (1 female), NHMW 29570 (1 male, 1 female), MPEG PSE 000012 (1 male), MNRJ 10417 (1 male); 2 females, same collection locality and collector as for holotype, December 2019, MNRJ 10418 (1 female), MPEG PSE 000012 (1 female); 1 male, Caldas, Villamaría, Vereda Gallinazo, under bark of E. grandis, $5.015^{\circ} \mathrm{N}$, $75.439^{\circ}$ W, 2300 m, December 2019, F. García leg., ICN-APs-768.
Additional examined material. COLOMBIA: 2 males, Caldas, Villamaría, Vereda Gallinazo, $5.015^{\circ} \mathrm{N}, 75.439^{\circ} \mathrm{W}, 2300$ m, March 2021, F. García and D. Duque leg., under bark of $E$. grandis, ICN-APs-839.

Diagnosis. Cystowithius ankeri sp. nov. can be separated from the other four species of the genus as follows: from $C$. chamberlini by the granulate pedipalp hand (versus smooth in C. chamberlini), the strongly denticulate setae on the chelal hand (versus barely denticulate in C. chamberlini) and the tactile seta of tarsus IV situated in more distal position, i.e. subdistally (versus closer to mid-length of tarsus IV in C. chamberlini); from C. smithersi by the movable finger of the pedipalp being more than $0.70 \mathrm{~mm}$ (versus not exceeding $0.60 \mathrm{~mm}$ in C. smithersi); from $C$. colombicus and C. ecuadoricus by the comparatively smaller chela, i.e. chela (with pedicel) reaching $1.56 \mathrm{~mm}$ (versus less than $1.20 \mathrm{~mm}$ in the other species); from C. colombicus, $C$. ecuadoricus and $C$. smithersi by the male sternal invaginations present on the sternites VI-VIII (versus V-VIII in C. smithersi and C. ecuadoricus and VI-VII in C. colombicus). See also the identification key below.

Description. Habitus (Figs 1-3, 15): carapace and pedipalps dark red-brown; tergites and coxal region red-brown; legs redbrown, paler at base and darker distally. Carapace (Fig. 4): granulate, with 2 non-corneate eye spots, $1.26\left(\delta^{\Uparrow}\right), 1.20($ ( $) \times$ longer than broad; with ca. 66 (§), 45 (ㅇ) foliate setae, including $4(\hat{\partial},+)$ near anterior margin and $6(\hat{\partial},+)$ near posterior margin; with 2 deep furrows closer to posterior carapace margin than to anterior furrow. Chelicera (Figs 5, 6): with 5 setae on hand, bs and sbs denticulate, others acuminate; with 2 dorsal lyrifissures; galea $(\precsim)$ with 3 small terminal rami, (ㅇ) with 4 small terminal rami; rallum of 4 blades, first slightly serrated, others smooth; serrula exterior with 19-20 blades; lamina exterior present; Pedipalp (Figs 7, 8): trochanter, femur, patella and chelal hand granulate, with foliate setae; trochanter 1.65-2.00 (ð), 1.69-2.00 (ㅇ) , femur 5.20-5.72 (ð), 4.65-5.94 (ㅇ), patella 3.56-3.83 (ð), 3.28-4.44 (ㅇ), chela (with pedicel) 1.48-1.58 (ð), 1.56-1.62 (ㅇ), chela (without pedicel) 1.41-1.48 (ð), 1.48-1.58 (ㅇ), hand 2.00-2.34 (ठ), 1.75-2.00 (ㅇ) $\times$ longer than broad, movable finger 0.74-0.80 (§), 0.79-0.82 (ㅇ) $\times$ longer than hand. Fixed chelal finger with 8 trichobothria, movable chelal finger with 4 trichobothria: eb and esb situated basally; est, it, and isb grouped together submedially; ist and ib situated basally; $b$ and sb situated near one another; st closer to $b$ than to t.; distance between $t$ and the fingertip equal to st. Nodus ramosus not visible. Coxal region: maxilla with 2 apical setae, 1 sos and $25(\precsim)$, ca 27 (ㅇ) additional setae; median maxillary lyrifissure rounded, situated medially; posterior maxillary lyrifissure present, coxal chaetotaxy: (ð), 10:11:9:18; (+), 8: 10:9: 19. Abdomen (Figs 9, 10): tergites I-IX with yellowish suture line; tergal chaetotaxy: (ॐ), 10: 10: 9: 11: 12: 14: 12: 14: 13: 12: 11 (including 2 ts): 2; (), 8: 10: 10: 12: 14: 16: 15: 13: 12: 12 (including 4 ts): 2, all setae foliate; pleural membrane longitudinally striate; sternal 

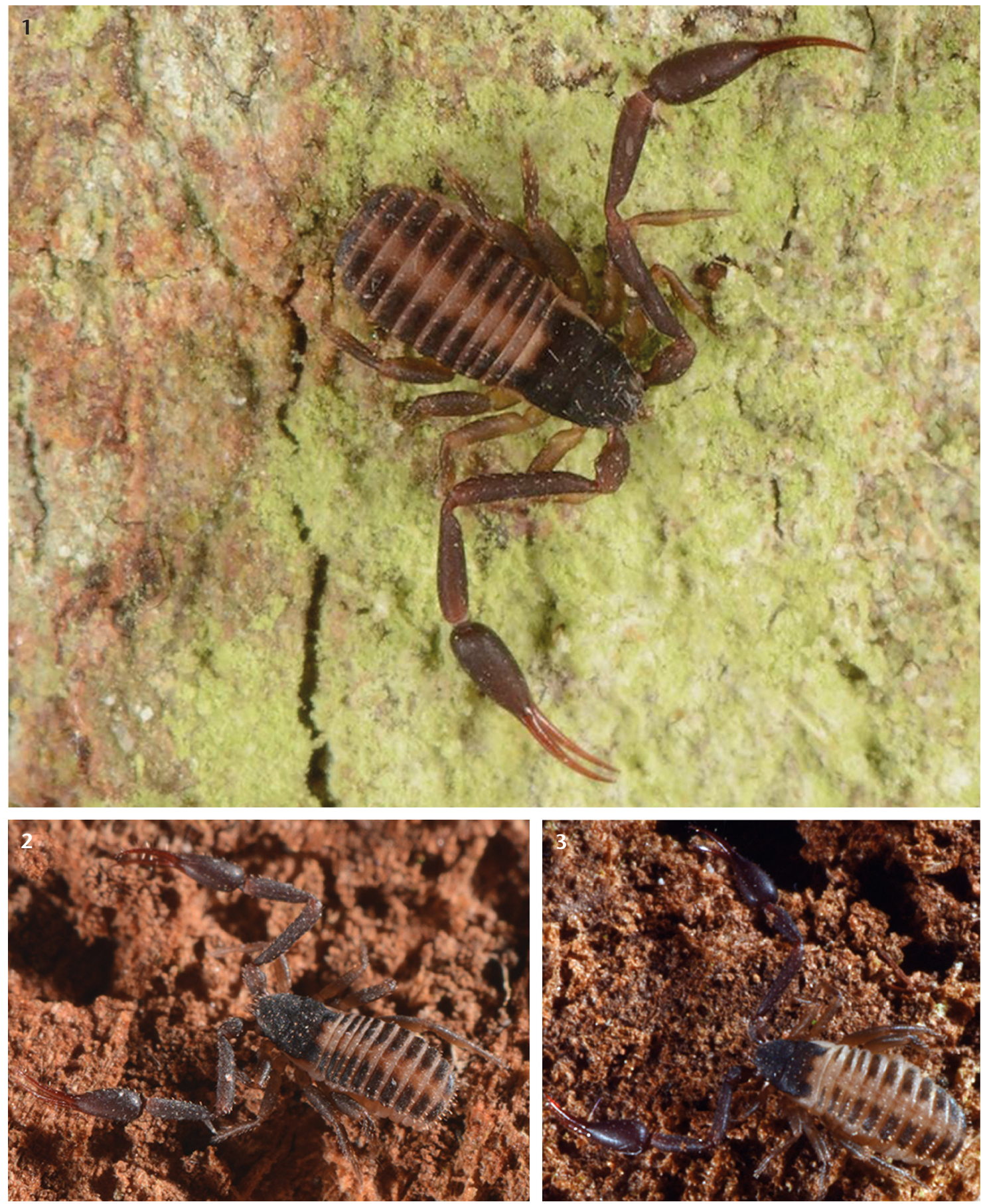

Figures 1-3. Cystowithius ankeri sp. nov. in situ, Jardín Botánico de la Universidad de Caldas, Manizales, Caldas, Colombia: (1) paratype male, ICN-APs682; (2) paratype male, ICN-APs-766; (3) paratype female, ICN-APs-767. Photographs by Arthur Anker.

chaetotaxy: (đ) $, 12:$ (1) 9 (1): (2) 12 (2): 15: 16: 13:14 + 44/46 gls: $11+1 / 1$ gls: 10: 12 (including 4 ts): 2 ; (), 10: (1) 12 (1): (2) 11 (2): 16: 16: 17: 17: 13: 10: 8 (including 4 ts): 2 , setae uniseriate and acuminate, except for setae on sternite XI, latter strongly denticulate; males with patches of small, conical, glandular setae on sternites VIII-IX and paired invaginations on sternites 

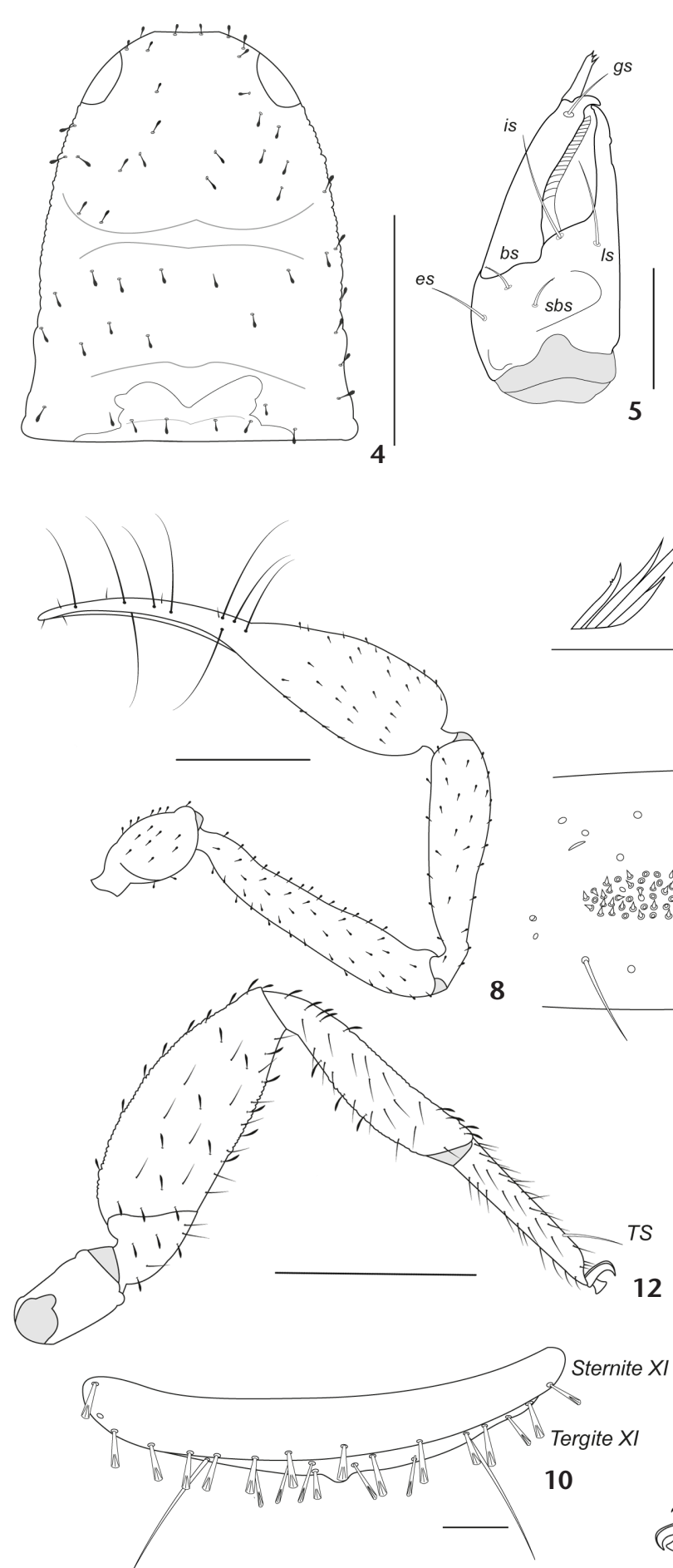

6

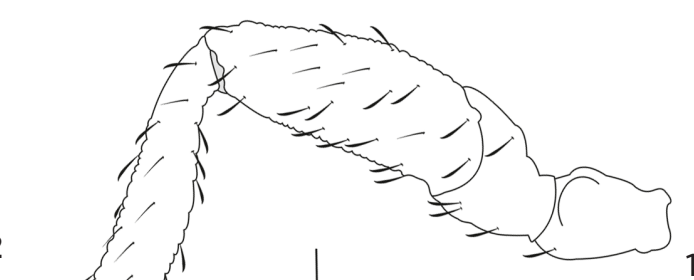

11

Figures 4-12. Cystowithius ankeri sp. nov., Jardín Botánico de la Universidad de Caldas, Manizales, Caldas, Colombia: (4-8, 10-12) holotype male, ICN-APs-837; (9) paratype male, ICN-APs-766. (4) Carapace, dorsal view; (5) left chelicera, dorsal view; (6) right rallum; (7) left chela showing trichobothrial pattern, retrolateral view; (8) right pedipalp, ventral view; (9) patches of glandular setae on sternite VIII; (10) sternite $\mathrm{XI}$ and tergite $\mathrm{XI}$; (11) left leg I, lateral view; (12) left leg IV, lateral view. Scale bars: $0.05 \mathrm{~mm}(10), 0.1 \mathrm{~mm}(5,9), 0.5 \mathrm{~mm}(4,7,8,11,12)$. 

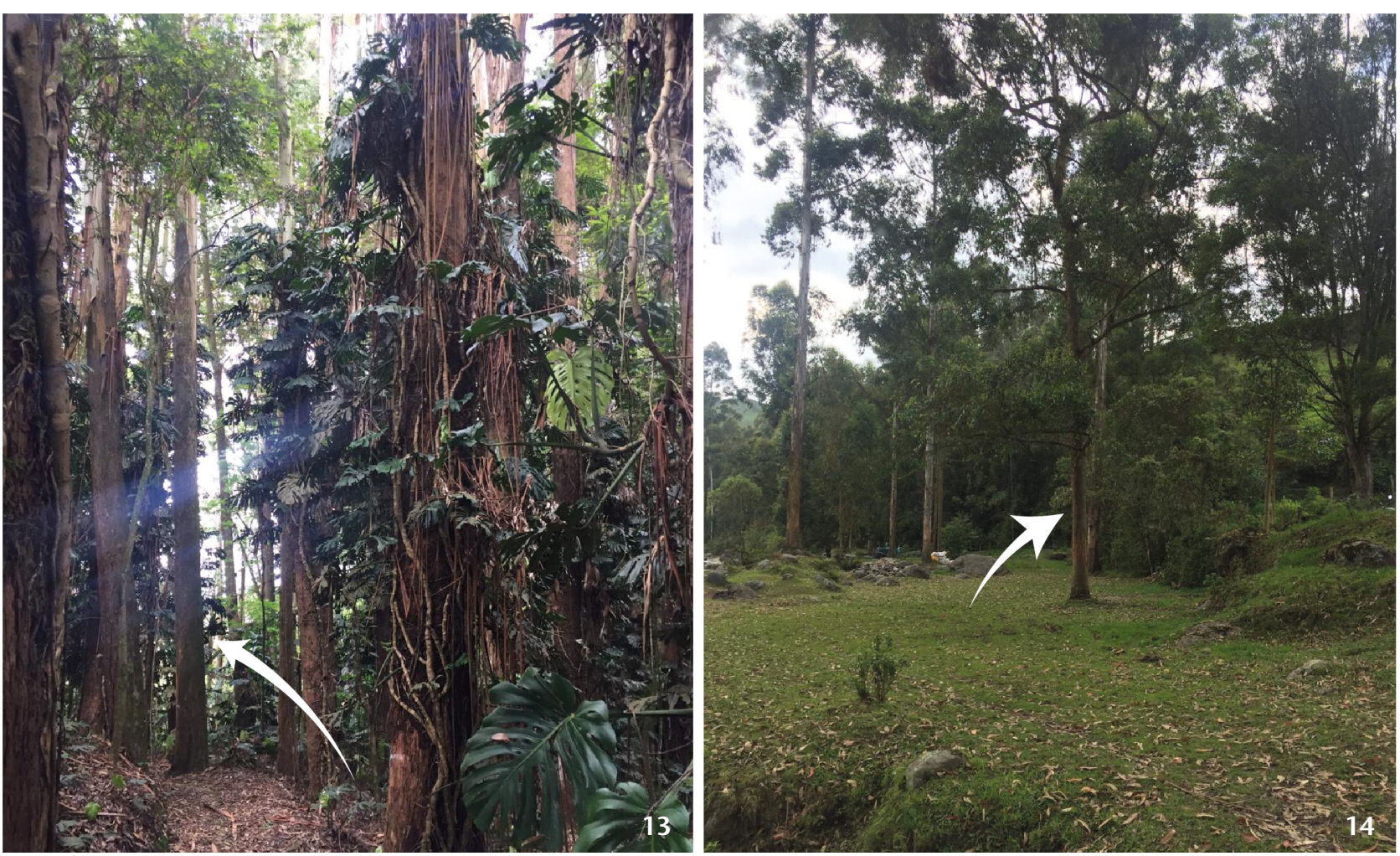

Figures 13-14. Habitat of Cystowithius ankeri sp. nov.: (13) type locality, Eucalyptus grandis alley, Jardín Botánico de la Universidad de Caldas, Manizales, Caldas, Colombia; (14) Eucalyptus grandis plantation, Vereda Gallinazo, Villamaría, Caldas, Colombia.

VI-VIII. Legs (Figs 11, 12): trochanter, femur, patella, tibia and tarsus of all legs granulate, with foliate setae; junction between femur and patella I parallel; femur + patella of leg IV 3.60 (ð), $5.00($ () $) \times$ longer than deep; tactile tarsal seta of leg IV situated subdistally (TS $=0.77\left({ }^{\Uparrow}\right)$ and $\left.0.68(+)\right)$ ); claws simple; arolium shorter than claws. Genitalia: ejaculatory canal projected in form of inverted triangle; dorsal apodeme sclerotization moderate to attenuate, reaching half or less of apodeme, straight throughout its length, wider at ejaculatory canal atrium; lateral apodeme extending at most to half-length of ejaculatory canal atrium, rounded basally, projected dorsally in lateral view; ejaculatory canal reaching one third of genital armature length, with rounded tip, sclerotized posteriorly, concave in lateral view; lateral rods straight, divergent dorsally, extending beyond lateral apodemes in dorsal view.

Dimensions. Males: holotype followed by six paratypes in parentheses. Pedipalp: trochanter 0.48/0.24 (0.4-0.44/0.2$0.26)$, femur $1.04 / 0.2(0.82-1.06 / 0.18-0.20)$, patella $0.92 / 0.24$ (0.82-0.89/0.23-0.25), chela (with pedicel) 1.56 (1.48-1.58), chela (without pedicel) 1.48 (1.41-1.51), hand length $0.78 / 0.36$ (0.66-0.78/0.33-0.34), movable finger length 0.8 (0.74-0.79). Carapace: 0.96/0.84. Leg I: trochanter 0.23/0.24, femur $0.19 / 0.19$, patella $0.42 / 0.160$, tibia $0.46 / 0.11$, tarsus $0.368 / 0.07$. Leg IV: femur/patella $0.95 / 0.26$, tibia $0.60 / 0.14$, tarsus
0.424/0.336. Females: Paratype (ICN-APs-767) followed by five paratypes in parentheses. Pedipalp: trochanter 0.50/0.24 (0.44$0.46 / 0.25)$, femur 1.04/0.2 (1.07/0.18-0.23), patella 0.86/0.22 (0.82-0.84/0.18-0.23), chela (with pedicel) 1.58 (1.56-1.62), chela (without pedicel) 1.50 (1.48-1.58), hand length $0.80 / 0.40$ (0.72-0.74/0.36-0.41), movable finger length 0.8 (0.77-0.82). Carapace: $1.0 / 0.9$. Leg I: femur $0.20 / 0.20$, patella $0.44 / 0.13$, tibia 0.41/0.08, tarsus 0.38/0.06. Leg IV: trochanter 0.32/0.19, femur/ patella $0.88 / 0.24$, tibia $0.60 / 0.12$, tarsus $0.43 / 0.08$.

Distribution. Cordillera Central of the Colombian Andes: presently known only from Manizales and Villamaría areas of Caldas.

COI barcode. GenBank accession number MT085822 (paratype, ICN-APs-682).

Etymology. This species is named after Dr. Arthur Anker, a zoologist with broad interests, who participated in the discovery of this new species.

\section{DISCUSSION}

The Central Cordillera in Colombia is part of the vast northern extension of the Andes. This mountain system is one of the richest biodiversity zones in the world, mainly due to formation of numerous ecological niches during its uplift (Hazzi 


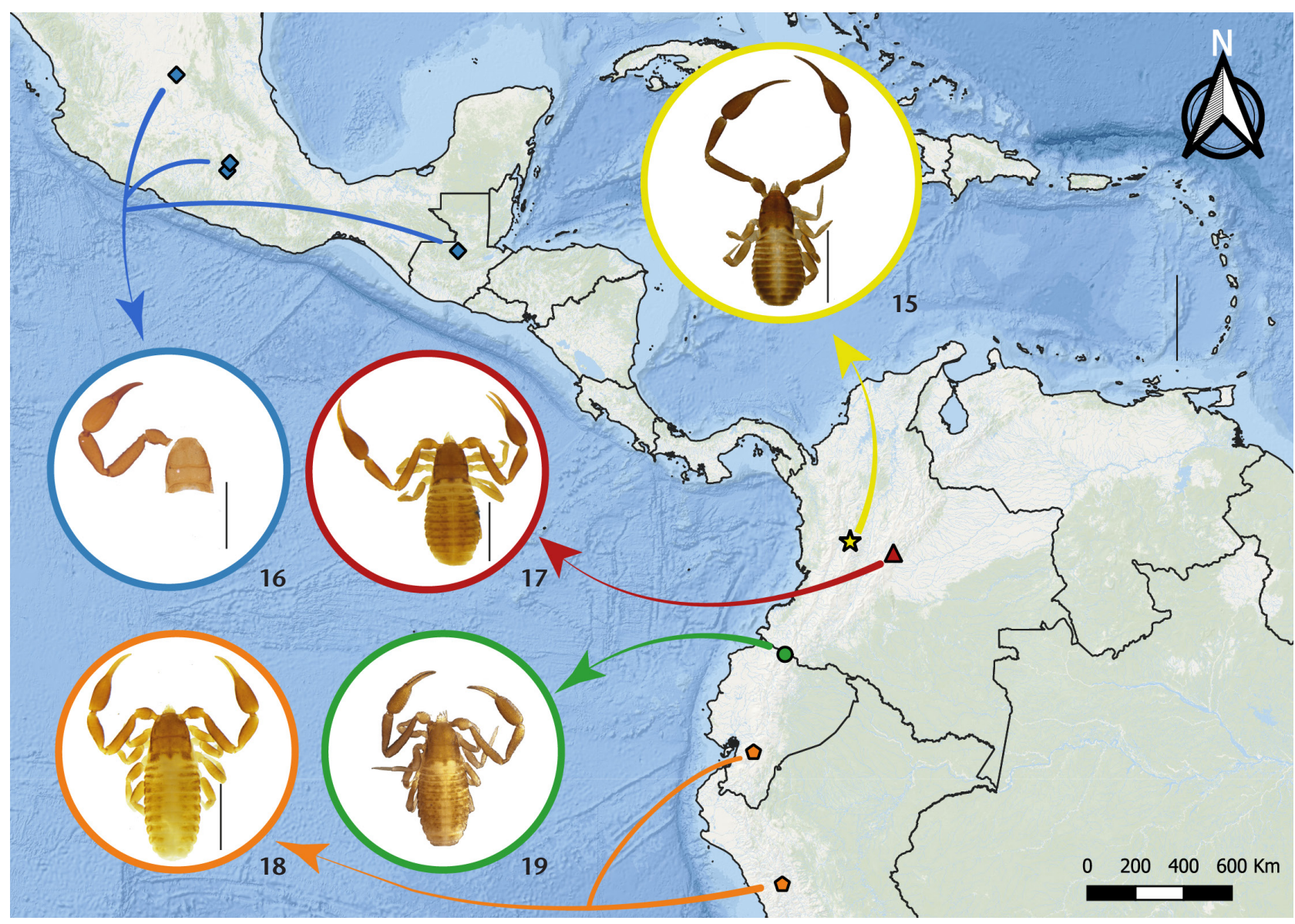

Figures 15-19. Male specimens and distribution records of five species of Cystowithius: (15) C. ankeri sp. nov., paratype, MPEG PSE 000012; (16) C. chamberlini, incomplete holotype, CAS 18448; (17) C. colombicus, paratype, NHMW 24058; (18) C. ecuadoricus, paralectotype, NHMW 24056; (19) C. smithersi, paratype, MNHN, no number provided. Scale bars: $0.5 \mathrm{~mm}(15,16) ; 1 \mathrm{~mm}(17,18)$; without scale $(19)$.

et al. 2018). Caldas and Quindio departments are located in the Central Cordillera, with much of the southern regions dominated by the transformation of the natural forest into coffee plantations (Gulh 2008). This change in land use resulted in new vegetation types, including the extensive planting of exotic trees, such as Eucalyptus spp., for economic purposes (Molina-Franco 2017). Eucalyptus trees have deleterious effects on soil properties (Zhang et al. 2012), but the bark may serve as a link between the canopy and the leaf litter, with many different arthropods using bark niches as shelter and to search for food in the litter below (Majer et al. 2003).

Cystowithius ankeri sp. nov. is presently known only from the Cordillera Central, around Manizales and Villamaría, Caldas, where it may be found under the bark of Eucalyptus grandis W. Hill ex Maiden (Myrtaceae) (Figs 13, 14). This eucalyptus species was introduced to Colombia from Queensland and New South Wales, Australia (Ospina et al. 2006), and was planted in the Botanical Gardens of the University of Caldas (Jardín Botánico de la Universidad de Caldas) in the 1980s. Like all species of Cystowithius, C. ankeri sp. nov. is found at higher altitudes (2150 $\mathrm{m}$ in Manizales and $2300 \mathrm{~m}$ in Villamaría).

Some specimens of $C$. ankeri sp. nov. were found under the bark of $E$. grandis; however, it was also common to observe females walking on the bark during the morning hours (8:00-10:00 am). On the other hand, males were more commonly observed outside of the bark in the late afternoon and first hours of the night. Each tree examined between 0 and $2 \mathrm{~m}$ of the trunk had about 10-30 individuals. Social behavioral interactions were not observed and neither was parental care. Males and females of C. ankeri sp. nov. were initially placed in separate Petri dishes, where they remained for some hours. However, we observed that some larger males were aggressive towards smaller males, thus showing some dominance behavior. Generally, it would be interesting to study some ecological and biological aspects of C. ankeri sp. nov., especially in situ behavior, niche occupation and dispersal. 
The native tree host of $C$. ankeri sp. nov. is currently unknown. The other three Andean species of Cystowithius were collected in the Paramo, for instance, C. smithersi in the leaf sheath of Espeletia pycnophylla Cuadrec (Harvey 2004). The two collection localities of $C$. ankeri sp. nov., i.e. Jardín Botánico in Manizales and Vereda Gallinazo in Villamaría, are approximately 58 and $30 \mathrm{~km}$ away, respectively, from the nearest Paramo habitats and it is possible that $C$. ankeri sp. nov. may eventually be found there as well.

Cystowithius could represent an interesting model for biogeographical studies, given the recent and complete descriptions and redescriptions of the five presently known species (Harvey 2004, present study) and their interesting distribution patterns in Central and South America (Figs 15-19).

Identification key to the five presently known species of $\mathrm{Cy}$ stowithius, using mainly characters of the males (modified from Harvey 2004)

1. Chelal hand smooth; setae on chelal hand only barely denticulate; tactile setae of tarsus IV situated closer to its

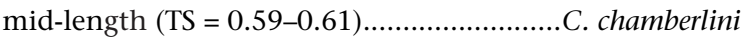

1 '. Chelal hand evenly granulate; setae on chelal hand distinctly denticulate; tactile seta of tarsus IV situated subdistally (TS $=0.68-0.79)$

2. Movable finger of pedipalp more than $0.70 \mathrm{~mm}$; males with sternal invaginations on sternites VI-VIII.

C. ankeri sp. nov.

2'. Movable finger of pedipalp less than $0.60 \mathrm{~mm}$; males with sternal invaginations on sternites V-VIII or VI-VII ......... 3

3. Pedipalps longer and more slender, i.e. chela (with pedicel) longer than $1.35 \mathrm{~mm}$............................... . smithersi

3'. Pedipalps shorter and more robust, i.e. chela (with pedicel) shorter than $1.20 \mathrm{~mm}$

... 4

4. Setae on tergite XI short and strongly clavate; chelal hand without long, strongly denticulate setae

C. colombicus

$4{ }^{\prime}$. Setae on tergite XI long and only slightly clavate; chelal hand with long, strongly denticulate setae

C. ecuadoricus

\section{ACKNOWLEDGEMENTS}

We thank Christoph Hörweg (NHMW), Rachel Diaz-Bastin (CAS) and Mark Judson (MNHN) for taking and sending photographs of the type specimens of Cystowithius spp.; Adriano B. Kury (MNRJ), Alexandre B. Bonaldo and Izaura da Conceição Magalhães (MPEG), and Jimmy Cabra (UNIVALLE), for their assistance during the deposition of the type material; Edgar Linares (ICN), Eduardo Florez (ICN), Fabiola Ospina and Jaime Estevez (Universidad de Caldas) for their permission to use laboratory equipment; and Arthur Anker (Universidade Federal de Goiás) for taking and making available color photographs of the new species. We also thank Mark Harvey (Western Australian Museum) and an anonymous reviewer, whose constructive comments considerably improved the quality of the originally submitted manuscript. FG thanks Jithin Johnson (Sacred Heart
College), Andrés Better (Colorado State University), Sofía Terán Sánchez, Daniel Duque, Juan Mateo Rivera and Helen Salazar Peña (Universidad de Caldas) for their general help and support during this study. CRO thanks Carlos Sarmiento (ICN) for his advice and support.

FG was supported by Programa Tatiana Carvalho, Greenpeace, Brazil. CRO is grateful to Colciencias for financial support during her PhD studies through the "Doctorados Nacionales 727-2015" fellowship.

\section{LITERATURE CITED}

Beier, M (1959) Zur Kenntnis der Pseudoscorpioniden Fauna des Andengebietes. Studies on Neotropical Fauna and Environment 1(3), 185-228.

Chamberlin JC (1931a) The arachnid order Chelonethida. Stanford University Publications, Biological Sciences 7(1), Stanford, California, 284 pp.

Chamberlin JC (1931b) A synoptic revision of the generic classification of the chelonethid family Cheliferidae Simon (Arachnida). Canadian Entomologist 63: 289-294.

Coleman CO (2009) Drawing setae the digital way. Zoosystematics and Evolution 85(2): 305-310. https://doi.org/10.1002/ zoos. 200900008

Folmer O, Black M, Hoeh W, Lutz R, Vrijenhoek R (1994) DNA primers for amplification of mitochondrial cytochrome $\mathrm{c}$ oxidase subunit I from diverse metazoan invertebrates. Molecular Marine Biology and Biotechnology 3(5): 294-299.

Guhl A (2008) Coffee production intensification and landscape change in Colombia, 1970-2002. In: Millington A, Jepson W (Eds) Land-Change Science in the Tropics: Changing Agricultural Landscapes. Springer Science \& Business Media, 93-115.

Harvey MS (2004) Remarks on the New World pseudoscorpion genera Parawithius and Victorwithius, with a new genus bearing a remarkable sternal modification (Pseudoscorpiones, Withiidae). Journal of Arachnology 32(3): 436-456. https:// doi.org/10.1636/S03-48

Harvey MS (2015) Revised diagnoses for the pseudoscorpion genera Metawithius and Microwithius, with the description of a new Australian genus, and notes on Withius (Pseudoscorpiones, Withiidae). Journal of Arachnology 43(3): 353-370.

Hazzi NA, Moreno JS, Ortiz-Movliav C, Palacio RD (2018) Biogeographic regions and events of isolation and diversification of the endemic biota of the tropical Andes. Proceedings of the National Academy of Sciences 115(31): 7985-7990. https://doi.org/10.1073/pnas.1803908115

Judson M (2007) A new and endangered species of the pseudoscorpion genus Lagynochthonius from a cave in Vietnam, with notes on chelal morphology and the composition of the Tyrannochthoniini (Arachnida, Chelonethi, Chthoniidae). Zootaxa 1627: 53-68.

Majer JD, Recher H, Graham R, Gupta R (2003) Trunk invertebrate faunas of Western Australian forests and woodlands: 
influence of tree species and season. Austral Ecology 28(6): 629-641. https://doi.org/10.1046/j.1442-9993.2003.01320.x

Molina-Franco D (2017) Un australiano en Bogotá. Los árboles de eucaliptos y la transformación del paisaje capitalino (1870-1930). In: Asociación Colombiana de Historiadores. Memorias. XVIII Congreso Colombiano de Historia, Medellín, Colombia, 80-93.

Murienne J, Harvey MS, Giribet G (2008) First molecular phylogeny of the major clades of Pseudoscorpiones (Arthropoda: Chelicerata). Molecular phylogenetics and evolution 49(1): 170-184. https://doi.org/10.1016/j.ympev.2008.06.002

Ospina CM, Hernández RA, Rodas CA, Urrego JB, Godoy JA, Aristizabal FA, Osorio OI, Riaño NM (2006) Guías silviculturales para el manejo de especies forestales con miras a la producción de madera en la zona andina colombiana: El eucalipto Eucalyptis grandis W. Hill ex Maiden. Ospina, H.F., Cenicafé. Available from www.cenicafe.org/es/publications/ eucalipto.pdf [accessed 30 Oct. 2019].

Romero-Ortiz C, Sarmiento C (2021) A comparative study of the male genitalia of the Cacodemoniini (Pseudoscorpiones: Withiidae). Journal of Arachnology 49(1): 108-121. https://doi.org/10.1636/JoA-S-19-068

Zhang D, Zhang J, Yang W, Wu F (2012) Effects of afforestation with Eucalyptus grandis on soil physicochemical and micro- biological properties. Soil Research 50(2): 167-176. https:// doi.org/10.1071/SR11104

Submitted: June 13, 2021

Accepted: August 25, 2021

Editorial responsibility: Ricardo Pinto da Rocha

\section{Author Contributions}

FG and CR prepared the text together; FG prepared all illustrations; CR did DNA sequencing. Both authors revised and approved the final of the version of the text.

\section{Competing Interests}

The authors have declared that no competing interests exist.

\section{How to cite this article}

García F, Romero-Ortiz C (2021) Cystowithius ankeri sp. nov., a new pseudoscorpion from the Central Andes of Colombia (Arachnida: Pseudoscorpiones: Withiidae). Zoologia (Curitiba) 38: e21003. https://doi.org/10.1590/S1984-4689.v38.e21003

\section{Published by}

Sociedade Brasileira de Zoologia at Scientific Electronic Library

Online (https://www.scielo.br/zool)

Copyright

(c) 2021 The Authors. 